International Journal of Current Advanced Research

ISSN: O: 2319-6475, ISSN: P: 2319 - 6505, Impact Factor: SJIF: 5.995

Available Online at www.journalijcar.org

Volume 6; Issue 5; May 2017; Page No. 3783-3786

DOI: http://dx.doi.org/10.24327/ijcar.2017.3786.0367

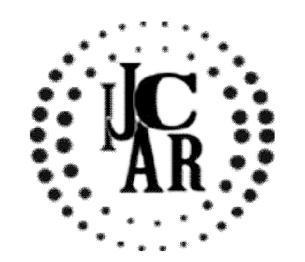

Case Study

\title{
APPLICATION OF LED IN SURFACE MINES - A CASE STUDY
}

\author{
Aruna M1., Lakshmipathy ${ }^{2}{ }^{2}$, Abhishek Kumar Tripathi ${ }^{3}$ and Murthy Ch.S.N ${ }^{4}$ \\ ${ }^{1}$ Department of Mining Engineering National Institute of Technology Karnataka, Surathkal, \\ Mangalore-575025, Karnataka, India \\ ${ }^{2}$ Department of Electrical \& Electronics Engg., Dr.TTIT, Oorgaum, K.G.F - 563120, India \\ ${ }^{3,4}$ Department of Mining Engineering National Institute of Technology Karnataka, \\ Surathkal, Mangalore-575025, Karnataka, India
}

\section{A R T I C L E I N F O}

\section{Article History:}

Received $24^{\text {th }}$ February, 2017

Received in revised form $12^{\text {th }}$ March, 2017

Accepted $8^{\text {th }}$ April, 2017

Published online $28^{\text {th }}$ May, 2017

\section{Key words:}

Illumination, Lux, Light source, LED

\begin{abstract}
A B S T R A C T
In surface mines where natural light is not available, especially during night hours, artificial light is provided for better seeing, which facilitates increased production, reduces worker's fatigue, protects their health, eyes and nervous system, and reduces accidents. The important aspect of lighting design is to provide sufficient illuminance on visual tasks. Scientific design of artificial lighting is very important to fulfill the lighting standards as prescribed by various regulatory bodies. The factors like type of luminaire, mounting height, pole interval, aiming angle etc., govern the design of lighting installation. As a case study, an illumination survey was carried out in a limestone mine and its existing lighting system is redesigned with different lighting sources, with the help of developed design model. This study demonstrated that by adopting the optimal design parameters in mine illumination, the minimum required lighting standards could be fulfilled and the total annual cost would come down to approximately $47 \%$.
\end{abstract}

Copyright $₫ 2017$ Aruna M et al. This is an open access article distributed under the Creative Commons Attribution License, which permits unrestricted use, distribution, and reproduction in any medium, provided the original work is properly cited.

\section{INTRODUCTION}

A surface mine which consists of several square kilometers of land and where mining operations are carried out round the clock, systematic artificial lighting is necessary for providing safe and efficient working environment. In view of huge investment involved in mining projects, which involve powerful, large and heavy mobile equipment's, good working condition during night hours for increased productivity is a necessary (Anon, 1961; Anon, 1984; Mayton et al., 1991). One major problem of lighting in surface mines is continuous changing of work place including haul roads within pit limits (Bandhopadhyay et al., 1989; Bandhopadhyay et al., 1991). Because of this, it is almost impossible to provide any kind of long term permanent structure for illumination. The shifting or erection of poles at regular intervals becomes necessary so as to ensure required light level as per the specified standards recommended by the Directorate General of Mines Safety (DGMS) for minimum illuminance level for various parts of mine.

In mines, where scientific design methodology for illumination is not practiced, light level at patches may be far below the standards.

\section{*Corresponding author: Aruna M}

Department of Mining Engineering National Institute of Technology Karnataka, Surathkal, Mangalore-575025, Karnataka, India
To achieve the minimum illumination standards and for economics of lighting system, illumination system should be designed considering various parameters, such as pole height, spacing between poles, tilt angle of luminaire etc. There are two methods of designing lighting system: lumen method and point-by-point method. Between these two methods point-bypoint method is an accurate method of designing lighting system, in which illuminance level is computed at any point on the work place (Bommel et al., 1980).

In India, the mine lighting standard is based on the illuminace level i.e. light falling on the surface. The important aspect of lighting design is to provide sufficient illuminance on visual tasks. The illuminance level, distribution of light (i.e. uniformity) and glare are the three important design parameters, which influence the visibility during night times. However, glare is not a major problem in surface mines, as it can be easily avoided by mounting the luminaries high enough to be out of the vision field. Further, glare can also be reduced through proper angle of orientation of the luminaire.

\section{Importance of Lighting Design}

In many projects lighting is often the last item to be considered while estimating costing. Because of this low budgetary provision, the lighting installation may result in bad working environment, which may decrease human efficiency and increase accidental rate, thus affecting the expected 
performance of that project. It is therefore essential to design an energy efficient and cost effective lighting system in the early phase of the project for better working environment. This is possible with proper selection of design parameters. The light design parameters are decided based on the minimum illumination standards, which can be obtained from various combinations of design features of the illumination system. But in each case the energy consumption would be different and is the single highest cost component of any illumination system in the long run (Bright et al., 1949). Optimization of energy consumption in the illumination design would therefore reduce the overall lighting cost. But sometimes energy consumption by two lighting systems may be the same, in spite of its varied design parameters. In such cases, selection of optimum lighting design parameters is taken based on the total annual cost of entire lighting project. It comprises of fixed annual cost, running cost which includes maintenance cost. Among the said cost components, fixed annual cost mainly depends on the type of luminaire and the height of mounting (Bright et al., 1949).

\section{Development of Design and Cost Model}

Advances in the lighting technology have shown that there is tremendous scope for energy conservation in lighting system (Kurian et al., 2002). Consequently, cost effective lighting installations have become synonymous with energy efficient lighting systems (Bright et al., 1949). Hence, a scientific approach in the illumination design would contribute to efficient lighting without much addition to the total mining project cost (Karmakar et al., 2002; Karmakar et al., 2004).

While calculating illuminance, one may wish to know the illuminance at a specific point or may be interested in the average uniform horizontal illuminance across the work plane. Based on this principle, there are two methods of design techniques: lumen method and point-by-point method. The lumen method applies only to regular arrays of luminaires (Durrant et al., 1977; Ronald et al., 1991). For other arrangements it is necessary to calculate the effect of individual luminaires at particular points to get the net illuminance. In these situations the point-by-point approach is adopted.

Based on two basic laws of lighting i.e. inverse square law and cosine law a general equation was developed, as given in Equation 1, for design of lighting system based on point by point by method. Using this equation for any type of lighting system the design parameters can be optimized so as to fulfill the minimum lighting standards as prescribed by the various regulatory bodies. Further, a set of equations were also formulated for calculating the annual cost of entire lighting project. The total annual cost is the sum of fixed annual cost, annual running cost and annual maintenance cost.

$$
E_{h}=\sum \frac{I\left(c_{m}, \gamma_{m}\right) \times U F}{r_{m}{ }^{2} \times I M F} \times \cos \gamma_{m}
$$

where,

$\mathrm{E}=$ horizontal illumination level, in lux

$\mathrm{I}=$ luminance intensity, in lumen

$\mathrm{C}=$ horizontal angle between the line joining the point of measurement and the pole

base with the kerb line of the road, in degree $\gamma=$ vertical angle between the vertical and the line joining the source to the point of

measurement, in degree

$\mathrm{r}=$ inclined distance (in meters) from the source to the point of measurement, $\mathrm{m}$.

$\mathrm{UF}=$ utilization factor, and

$\mathrm{IMF}=$ inverse maintenance factor

\section{Case Study}

As a case study a limestone mine is considered, in which $2 \times 40 \mathrm{~W}$ FTL lamps were used for illuminating haul roads. The heights of poles were $8 \mathrm{~m}$, placed $2 \mathrm{~m}$ beyond the kerb of the roadway. The lamps were mounted on light arms of $2 \mathrm{~m}$ length having $30^{\circ}$ tilt angle. The width of the roadway was $12 \mathrm{~m}$. The spacing between the poles was ranging from $19 \mathrm{~m}$ to $21 \mathrm{~m}$. The measured horizontal illuminance levels along this roadway show that in some of the patches the illuminanance level is below 0.5lux (minimum required illuminance level as per DGMS). It may be due to large spacing between poles and improper orientation of lamps, in some of the locations. Also, because of this, in many stretches of roadway the uniformity ratio is below 0.3 (minimum uniformity ratio required as per CIE and BIS standards). For redesign of lighting system a stretch of haul road of $860 \mathrm{~m}$ length is selected. Figure 1 shows the existing lighting system along the length of roadway.

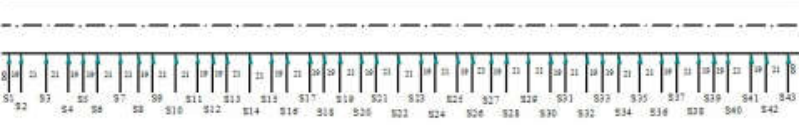

All dimensioos are in $\mathrm{n}$

Fig 1 Existing lighting system with 2x40W FTL lamps

Table 1 Input parameters for the programme

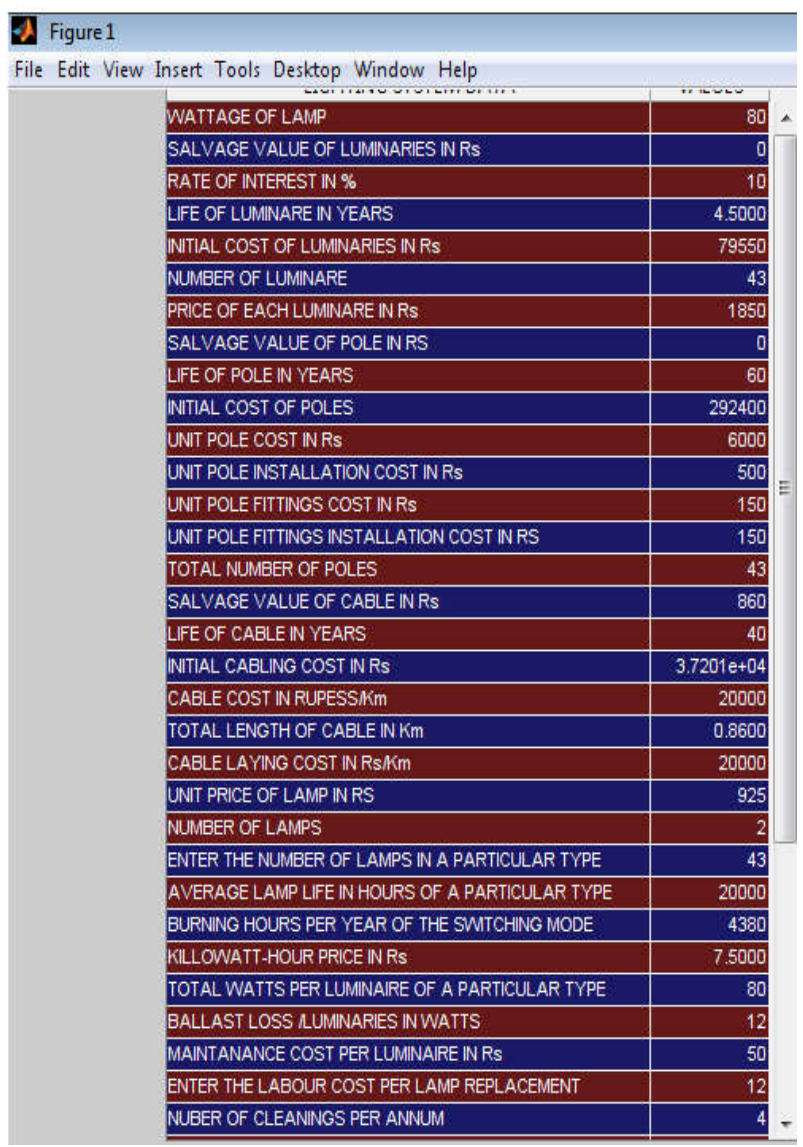


There were total 43 poles of $8 \mathrm{~m}$ height. Using developed cost model total annual cost for the existing lighting system is computed. Table 1 gives the input parameters for the programme. Table 2 represents the output of the computer programme for the respective lighting system shown in Figure 1. The total annual cost for the existing lighting system is $]$ $59,574 /-$.

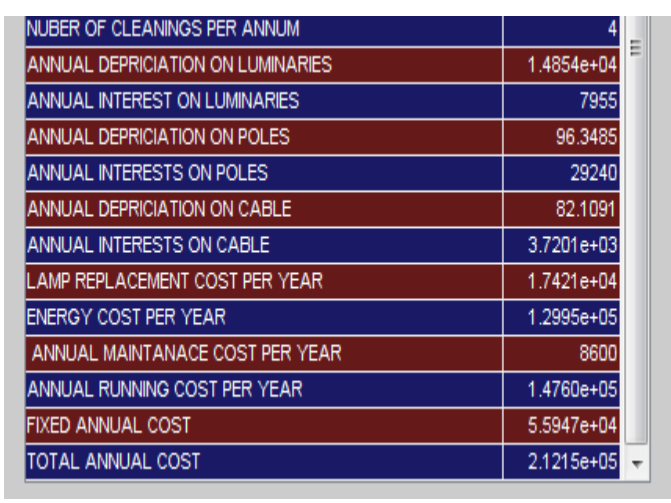

Table 2 Output of the cost programme

\section{Redesign of Existing Lighting System}

The existing lighting system (i.e. with 2 x40W FTL) is redesigned by adopting optimum lighting design parameters and by doing this the number of poles increased to 48 . Figure 2 shows the proposed lighting system with $2 \times 40 \mathrm{~W}$ FTL lamps mounted at $8 \mathrm{~m}$ height poles. Similarly, the lighting system is also designed for another five types of light sources, such as 100W HPSV, 70W HPSV, 80W HPMV, 70W MH and 24W LED. For redesign of lighting system, the tilt angle is taken as $14^{\circ}$ with $0 \mathrm{~m}$ light arm length (i.e. source is directly mounted on the pole). The pole height and their interval are selected based on the results as obtained from the design programme.

In mines, generally lamps were burning from $6 \mathrm{pm}$ to $6 \mathrm{am}$ i.e. for $12 \mathrm{hr}$. But some of the mines are operated only up to 10 pm. By keeping this in mind, the design is also made for LED source with micro controller based photosensor, which is placed on the body of the lamp.
When a natural day light reduces to an illuminance level of 60lux in the evening, the LED light automatically turn-on at rated voltage and it continues to glow at this voltage up to 12 mid night. From 12 midnight onwards till 6 am the LED source consumes only $50 \%$ of the rated voltage and the lux levels will be $50 \%$ of the rated lux. The LED light source will turn-off when the natural day light increases to a level of 6870lux in early morning hours. Table 3 and Table 4 gives the details of lighting parameters and total annual cost, respectively for all the redesigned lighting systems. However, for easy reference, design parameters and annual cost of existing lighting system is also indicated in these tables.

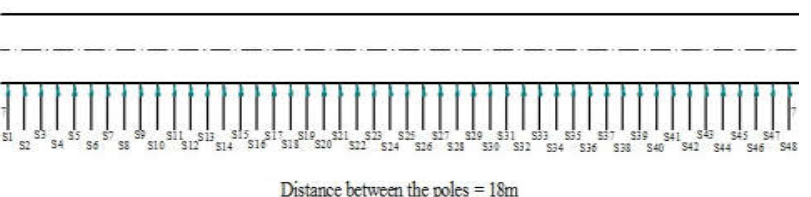

Fig 2 Proposed lighting system with 2x40W FTL lamps

\section{RESULTS AND DISCUSSION}

The total annual cost of the different lighting systems is given in the Table 4. Using the data of this table, a bar chart is drawn (which is shown in Figure 3), by plotting type of sources along $\mathrm{X}$-axis and total annual cost along $\mathrm{Y}$-axis. As shown in Figure 3, when the lighting system is redesigned with existing source, by adopting optimum design parameters (so as to fulfil the minimum lighting standards), there is an increase of $\square 24,293 /-(11.45 \%$ increase $)$ in total annual cost. But when the system is redesigned with 70W HPSV and $24 \mathrm{~W}$ LED sources, the annual cost will be below the redesigned system with $2 \times 40 \mathrm{~W}$ FTL sources. Among six types of sources the annual cost is the minimum for LED sources (i.e. $\square$ $1,22,591 /-)$. There is a reduction of $48.15 \%$ in annual cost when compared to redesigned system with existing light source. By incorporating micro controller based photosensor in LED sources, the annual cost is further reduced to $\square$ $1,12,539 /-$. This is mainly because of saving of $\square 10,052$ in annual running cost.

Table 3 Design parameters of existing and proposed illumination systems

\begin{tabular}{|c|c|c|c|c|c|c|c|}
\hline $\begin{array}{l}\text { Sl. } \\
\text { NO }\end{array}$ & $\begin{array}{c}\text { Illumin- } \\
\text { ation } \\
\text { System }\end{array}$ & $\begin{array}{l}\text { Type of } \\
\text { Source }\end{array}$ & $\begin{array}{l}\text { Mount- } \\
\text { ing } \\
\text { Height } \\
\text { (m) }\end{array}$ & $\begin{array}{c}\text { Pole } \\
\text { Spacing } \\
\text { (m) }\end{array}$ & $\begin{array}{c}\text { No. } \\
\text { of Pole }\end{array}$ & $\begin{array}{c}\mathbf{E}_{\min } \\
(\mathbf{l u x})\end{array}$ & $\mathbf{U}_{0}$ \\
\hline 1 & Existing & $2 \times 40 \mathrm{FTL}$ & 8 & $\begin{array}{c}\text { Not } \\
\text { uniform }\end{array}$ & 43 & lux level not adequate & below 0.3 \\
\hline 2 & Proposed & 2x40 FTL & 10 & 18 & 48 & satisfying minimum lux level & satisfying minimum level \\
\hline 3 & Proposed & 100W HPSV & 10 & 20 & 45 & satisfying minimum lux level & satisfying minimum level \\
\hline 4 & Proposed & 70W HPSV & 8 & 19 & 45 & satisfying minimum lux level & satisfying minimum level \\
\hline 5 & Proposed & 80W HPMV & 8 & 16 & 54 & satisfying minimum lux level & satisfying minimum level \\
\hline 6 & Proposed & 70W MH & 8 & 17 & 51 & satisfying minimum lux level & satisfying minimum level \\
\hline 7 & Proposed & 24W LED & 8 & 17 & 51 & satisfying minimum lux level & satisfying minimum level \\
\hline 8 & Proposed & 24W LED & 8 & 17 & 51 & satisfying minimum lux level & satisfying minimum level \\
\hline
\end{tabular}

Table 4 Annual cost of existing and proposed illumination systems

\begin{tabular}{|c|c|c|c|c|c|c|c|}
\hline SI. No. & $\begin{array}{c}\text { Illumination } \\
\text { system }\end{array}$ & $\begin{array}{l}\text { Type of } \\
\text { source }\end{array}$ & $\begin{array}{c}\text { Energy consumptior } \\
\text { (KWhr) }\end{array}$ & $\begin{array}{l}\text { FAC } \\
(\square)\end{array}$ & $\begin{array}{l}\text { ARC } \\
\text { ( } \square)\end{array}$ & $\begin{array}{c}\text { AMC } \\
\text { ( } \square)\end{array}$ & $\begin{array}{l}\text { TAC } \\
\text { ( } \square)\end{array}$ \\
\hline 1 & Existing & $2 \times 40 \mathrm{FTL}$ & 15067.20 & 55,947 & 147602 & 8600 & $2,12,149$ \\
\hline 2 & Proposed & 2x40 FTL & 16819.00 & 62010 & 164832 & 9600 & $2,36,442$ \\
\hline 3 & Proposed & 100W HPSV & 19710.00 & 76,200 & $1,95,587$ & 9,000 & $2,80,787$ \\
\hline 4 & Proposed & 70W HPSV & 13797.00 & 75,590 & $1,41,507$ & 9,000 & $2,26,097$ \\
\hline 5 & Proposed & 80W HPMV & 18921.60 & 87,515 & $1,85,080$ & 10,800 & $2,83,395$ \\
\hline 6 & Proposed & 70W MH & 15636.60 & $1,13,660$ & $1,87,876$ & 10,200 & $3,11,736$ \\
\hline 7 & Proposed & 24W LED & 5361.12 & 59,121 & 53,270 & 10,200 & $1,22,591$ \\
\hline 8 & Proposed* & 24W LED* & 5361.12 & 59,121 & 43,218 & 10,200 & $1,12,539$ \\
\hline
\end{tabular}




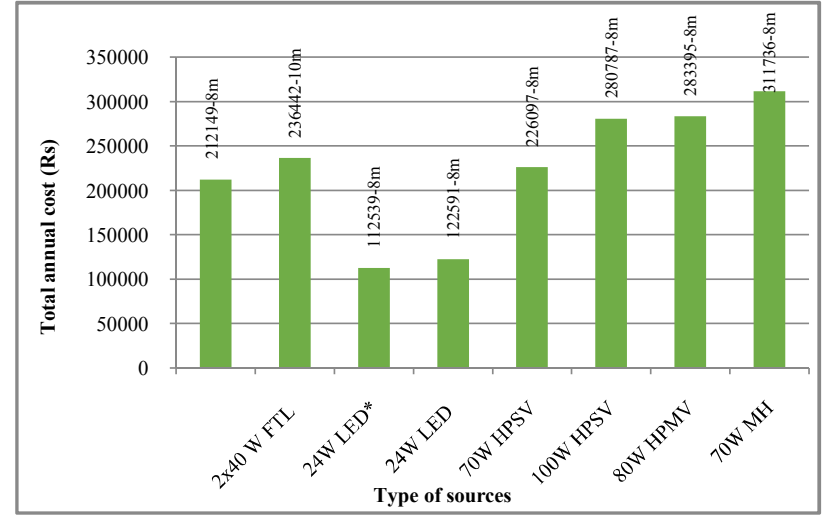

Fig. 3 Bar chart showing total annual cost for various types of sources

\section{CONCLUSIONS}

The case study of a mine shown that by adopting the optimal design parameters in mine illumination, the minimum required lighting standards could be fulfilled and the total annual cost would come down to approximately $47 \%$. Lamp selection is made mainly based on efficacy and suitability to each situation. Because of long life and high luminous flux, LED sources offers low total annual cost, with lowest energy consumption. However, due to efficient penetration character in dusty environment, which generally encountered in surface mines, HPSV lamps are giving very good performance. HPSV and LED lamps are recommended for surface mine lighting as they have high luminous flux as well as longer economic life compared to other types of light sources.

\section{References}

1. Anon., "Good Lighting...... What It Means in Coal Mining", Coal Age, June, 1961, pp. 85-90.

2. Anon., "Effective Mine Lighting Increases Safety, Productivity", Canadian Mining Journal, July, 1984, pp. 29-30.

3. Bright, A. A., The Electric Lamp Industry, Published by The Macmillan Company, New York, 1949.
4. Bell, B. W., "Lighting in Coal Mines", Proceedings of the Symposium on Environmental Engineering in Coal Mining, London, November, 1972, pp. 63-71.

5. Bommel, V. I. W. J. M. and de Boer, J. B., Road Lighting, Philips Technical Library, Kluwer Technische Bocken B. V., Deneter-Antwerpen, 1980.

6. Bandhopadhyay, K. P., "Lighting of Open Cast Mines", Proceedings of National Conference on Lighting for 21st century, Bangalore, 1989, pp. 36-41.

7. Bandhopadhyay, K. P., "Lighting of Open Cast Mines", Proceedings of International Conference on Lighting Technology, Prakash-91, New Delhi, 1991, pp. 254-259.

8. DGMS (Directorate General of Mines Safety, India) Circulars, Circular (Legis.) 1/1976 and 3/1976, 1976.

9. Durrant, W. D., Interior Lighting Design, Published jointly by the Lighting Industrial Federation Ltd. and the Electricity Council, Fifth Edition, London, April, 1977.

10. Kurian, P. C., Aithal, S. R., Bhat, J. and Colaco, G. S., "MATLAB'S Power for Interior Lighting Design", Proceedings of International Symposium, Lux Pacifica, September, 2002, pp. 260-263.

11. Karmakar, C. N. and Chauhan, S. B., "Illumination Survey And Cost Analysis For Large Scale Open Cast Coal Mine", Indian Mining \& Engineering Journal, April, 2002, pp. 29-32.

12. Karmakar, C. N. and Chauhan, S. B., "An Economic Analysis on Lighting of Opencast Mines By Light Tower", Minetech, vol. 25, no. 4, Jul-Aug, 2004, pp. 18-27.

13. Mayton, G. A., "Investigation of Task Illumination for Surface Coal Mining Equipment Operators", Journal of the Illuminating Engineering Society, Winter, 1991, pp. 2-18.

14. Ronald, H. N. and Belcher, C. M., Lighting for Energy Efficient Luminous Environments, Published by Prentice-Hall, New Jercy, Second Edition, 1991.

\section{How to cite this article:}

Aruna M et al (2017) 'Application Of Led In Surface Mines - A Case Study', International Journal of Current Advanced Research, 06(05), pp. 3783-3786. DOI:http://dx.doi.org/10.24327/ijcar.2017.3786.0367 